\title{
Seismic retrofit of historical masonry walls by means of natural basalt fiber strips system (BFRP). Pre-modern concepts and innovative materials
}

\author{
Giacomo Tempesta ${ }^{1, a}$ \\ ${ }^{1}$ Department of Architecture, University of Florence, Italy
}

\begin{abstract}
The paper deals with the design approach for post-seismic interventions aimed at safeguarding historical buildings in seismic areas, consisting prevalently of masonry structures that, by type of technology, even if within exceptional cases respectful of "the rule of art", do not guarantee the compliance with the resources necessary for the demand for resilient and structural capacity. In particular, the paper deals with the issue of applying technologies that use constructive ideas and concepts of the past or, as they are usually called pre-modern, reinterpreting them through the use of innovative and extremely performing materials.
\end{abstract}

\section{Introduction}

Going through the historical constructive solutions developed and used in past epochs to give an answer to the anti-seismic design problem, we note a great homogeneity from the point of view of the choice of materials and techniques used. Focusing on the Mediterranean Basin, the propensity for the use of mixed timber-masonry systems has been ascertained. This choice should not be surprising, since it was dictated by the mechanical features of timber that provide masonry walls with the capacity of withstanding the shear and bending actions provoked by an earthquake acting along the wall plan; a very limited capacity in unreinforced masonry. Already in Roman times timber members inserted, in a targeted way, within masonry walls were a widespread technique. Vitruvius himself [1] suggested the use of "travicelli d'ulivo brustolato per tutta la grossezza del muro" ("burnt Olive members within the entire thickness of the wall") to provide a link in such a way as "entrambe le fronti del muro [...] abbiano perpetua durata" ("both facings of the wall [...] can live forever"). Although the spread of timber-masonry techniques cannot be attributed only to the need of building anti-seismic constructions, most of these techniques were used in highly seismic areas of the entire Mediterranean Basin and that some specific constrictive systems were developed as a consequence of the occurrence of important seismic events.

Archaeological excavations carried out in the sites of Pompeii [2] and Herculaneum [3] in the $19^{\text {th }}$ century highlighted that the constructive technique based on the use of mixed timber-masonry, called Opus Craticium (Fig. 1a), was based on the use of a timber frame that divides the masonry wall in smaller portions, constituted

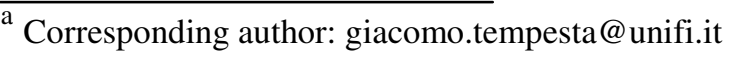

by transversal, vertical and bracing members joined together.

According to Bianchini [4], it is a building system that seems to be became established in Italy since the $6^{\text {th }}$ century and that, in a later time, continued to be used as an alternative to the stronger strcturae caementiciae, in rural buildings as well as in city dwellings, at the upper floors and to build internal partitions.

Even if it is much less known, the masonry "alla beneventana" is an interesting technique that anticipates the Bourbon "casa baraccata". It is referred to as a preferred construction technique for reconstruction after the Gargano earthquake occurred in 1627.

Its name being taken from the city of Benevento, it is constituted by a load-bearing timber frame with infill masonry: a set of posts fixed on a stone base and an infill of lightweight materials (such as wicker or reeds linked to chestnut laths), covered with mortar.
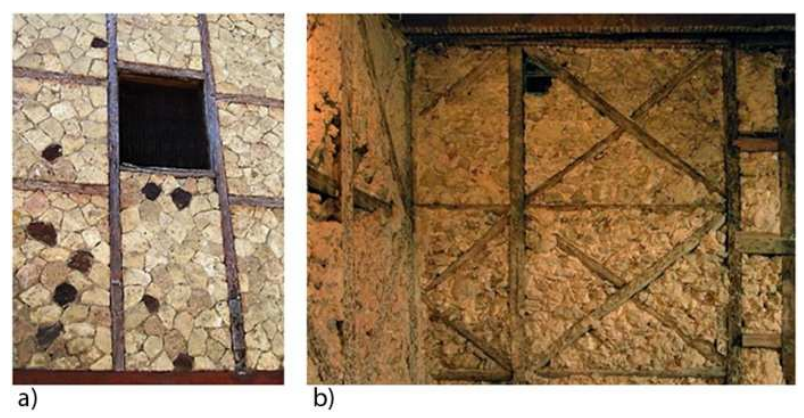

Figure 1. a) Opus Craticium; b) Gaiola Pombalina, 1775.

Thanks to the several surveys in the site of Irpina, carried out immediately after the strong seismic events occurred in 1980, it was ascertained that the structural response of the masonry "alla beneventana" was 


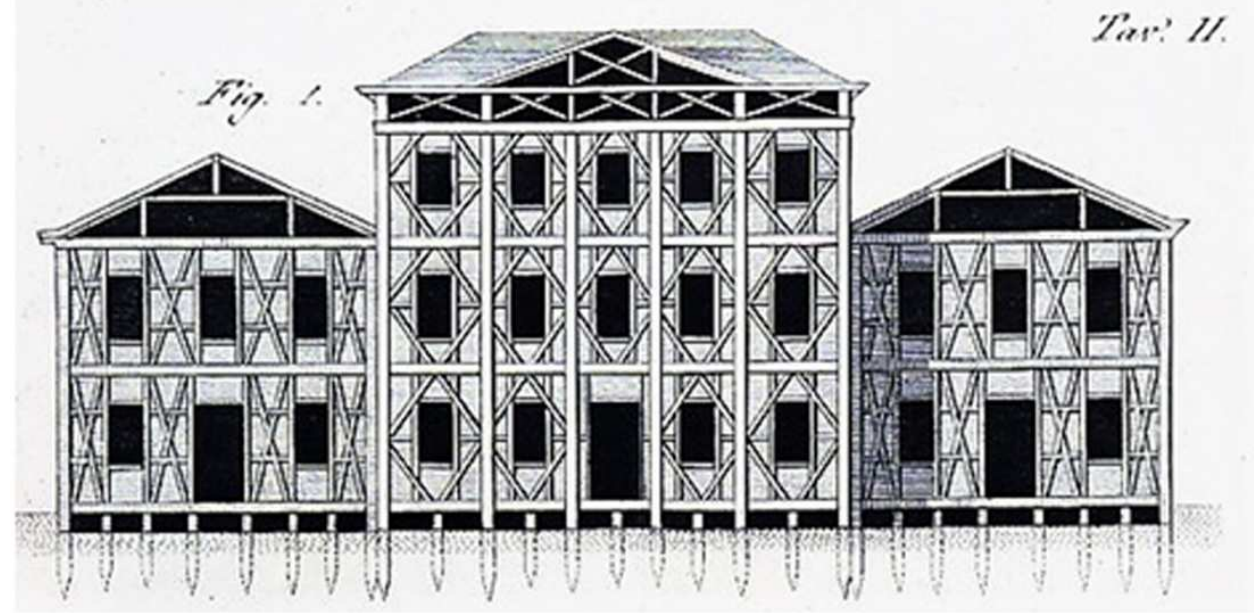

a)

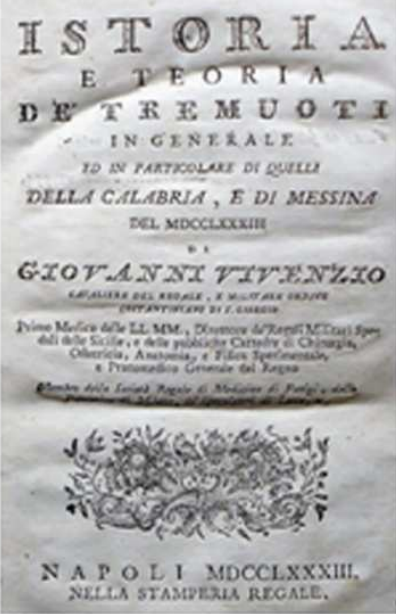

b)

Figure 2. Casa Baraccata: a) the sketch and b) the treatise by Giovanni Vivenzio, 1783.

performing and technologically functioning. Indeed, its success was due to the result obtained, consisting in partitioning walls in small portions, separated by wooden rods linked to the principal members, in which crack formation is allowed. Sometimes, some portions of the wall may also collapse, but the area of failure is reduced and is confined within the timber partitions.

Similar solutions were adopted in Turkey [5-6]: it's the case of the "hatul" and "himis" constructions, that resisted the earthquake in 1999. This constructive technique, of Ottoman origin, provides the building with a timber frame structure composed of vertical, horizontal and inclined members, filled with raw earth herringbone bond masonry. The "Dhajji dewari" is another timber frame with stone and earth infill, typically used in the mountain regions of South Asia.

"Gaiola", also called "Gaiola Pombalina" (Fig. 1b), is the building system conceived by Engineer Pombal for the post-seismic reconstruction of the Baixa area in Lisbon, immediately after the high magnitude earthquake occurred in 1775. Also this technique provides the use of a timber frame composed of posts and beams arranged in such a way as to form rather square portions. St. Andrew's crosses are inserted within each partition, with a brace function, together with an infill made of stone and brick masonry, usually recovered from rubble [7]. Masonry infill protrudes slightly from the timber frame, so that the positioning of a layer of covering plaster is allowed. At the end of the eighteenth century, the mixed timber-masonry constructive system, that is more appropriate to satisfy the anti-seismic requirements, is spreading. This technique derives from a fairly widespread tradition in timber constructions built in the Calabria region and filtered from the Enlightenment school of thinking that characterizes the era of the Bourbon domination in southern Italy.

Giovanni Vivenzio himself, doctor of the Royal Household and university professor, states that his earthquake resistant prototype, called "Case formate di legno (Houses built using timber members)" was deduced by the "[..]...osservazioni fatte sul luogo medesimo... (on-site inspections...)" such as, for example, “... Filogaso, l'antico Palazzo del Conte di Nocera ... costrutto nel passato secolo, di legno, e rivestito solamente di fabbrica, si rimase in tutto l'interiore illeso, nel mentre che il Paese fu uguagliato al suolo ... (... Filogaso, the ancient palace of the Count of Nocera ... built in the previous century using timber members and covered with masonry, that did not suffer damage inside, while all other buildings collapsed)" (Fig. 2). This system, denoted as "casa baraccata" or Bourbon anti-seismic system, was conceived by Engineer Ignazio La Vega after the Calabrian earthquake occurred in 1783. La Vega developed and improved this system on the basis of the knowledge and observations derived from the direction of the archaeological excavations of Pompeii and Herculaneum as well as from those obtained from examples already present in the traditional Calabrian building, such as the Bishop's building in Mileto.
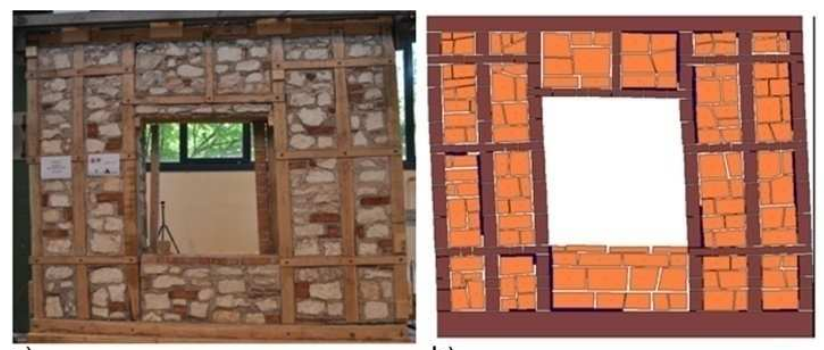

a)

b)

Figure 3. Ultimate deformed shape and cracking pattern. Comparison between experimental test (a) and numerical modeling through the software BrickWORK (b) [8].

By means of both experimental test carried out at the CNR Ivalsa in Trento (Italy) [8] and numerical models developed through the software BrickWORK [9-19], the efficiency of the Bourbon building system, in its various forms and configurations, and its great adaptability to the demand for structural resilience that is required to an anti-seismic constructive element, was demonstrated, in particular regarding its response to the in-plane horizontal actions (Fig. 3). This type of structure is able to dissipate energy by means of interface frictions that are generated 
by the slip of stones both between the infill of masonry and the timber frame, and also thanks to some fissures generated in the mortar, as well as the expulsion of few stones. The overall timber skeleton, both elements and joints, acts, during the cycles, in elastic field. The model, devoid of the infill masonry frame, highlights a weak behaviour characterized by a high deformability under cyclic actions.

\section{Palazzo Branconio. An experience of seismic retrofit}

Palazzo Branconio is a very important historical building located in the historic center of the city of L'Aquila and is the result of the aggregation of a series of buildings from the Middle Ages. The shape of the current building is the result of the transformations by Girolamo Branconio in the first half of the seventeenth century (Fig. 4).

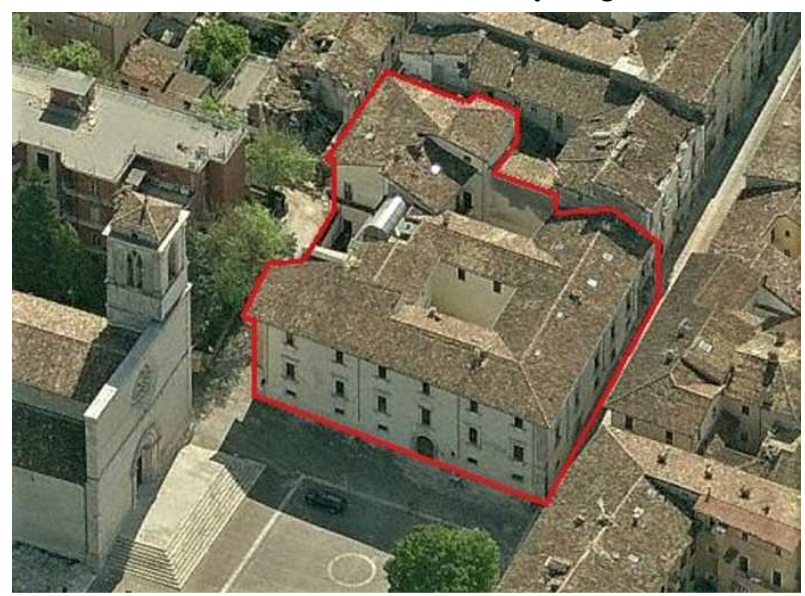

Figure 4. Palazzo Branconio, L'Aquila, Italy (picture taken from the author)

The Palace was already severely damaged by the earthquakes of 1703 and 1915, before suffering further damage from the very serious event of 6 April 2009. The spatial configuration of the building, although showing a sufficient regularity in elevation, although characterized by a decrease in thickness of the walls towards the upper floors, instead shows a substantial planimetric irregularity. This is due to the presence of walls built in different historical periods, according to distinct units and consisting of aggregates of main parts centralized on the two inner courtyards, together with a high reduction of wall thicknesses: these characteristics are the main reason of the greater concentration of crack patterns and damage in some rooms at the first floor (Fig. 5). The presence of such a heterogeneity was most likely to have provided the incipience, at the time of the earthquake, of kinematic movements caused by twisting actions, acting on the building due to the marked eccentricity between the rigid center of mass and that of the masses. The load-bearing walls of Palazzo Branconio is characterized by a typically L'Aquila brickwork technique, characterized by irregular stone elements, slightly rough-hewn, irregularly laid out, without transversal connections, with large amounts of mortar, having poor mechanical properties with fairly significant thicknesses, up to the first floor, at least 70 $\mathrm{cm}$. Only in some areas of the building it is possible to find sporadic squared stone cantons.

Some on-site experimental tests on masonry samples, aimed at evaluating the mechanical properties of the material, were carried out on some walls devoid of cracks, chosen inside the building. In particular, the panels were subjected to a diagonal compression test. In Tab.1 some significant average values are reported.

Table 1. Results of diagonal compression test

\begin{tabular}{|c|c|c|c|}
\hline Test & $\begin{array}{c}\text { Cross-section thickness } \\
(\mathrm{cm})\end{array}$ & $\begin{array}{c}\tau_{0} \\
(\mathrm{MPa})\end{array}$ & $\begin{array}{c}\mathrm{G} \\
(\mathrm{MPa})\end{array}$ \\
\hline $\mathrm{DC}-01 \mathrm{Br}$. & 70 & 0.033 & 111 \\
\hline
\end{tabular}

The experimental results on the walls of Palazzo Branconio provided both for the shear strength $\tau_{0}$ and shear elastic modulus $G$, values much lower than those deducible from the reference tables of the masonry technical rules, with a corresponding description of the typology of the masonry equipment (from masonry technical rules: $0.035 \leq \tau_{0} \leq 0.051 ; 230 \leq \mathrm{G} \leq 480$ ). In such a case these masonry walls show that the typical seismic failure mode is the diagonal cracking mode, when the principal tensile stresses develop in the masonry under a combination of vertical and horizontal loads exceeding the tensile strength of the masonry materials. Obviously, for the actions out of plan the propensity of the walls described above is to offer a strong vulnerability to the presence of combined compressive and bending stress, the latter even more dangerous for the overall stability of the building.

\section{Natural basalt fiber strips system (BFRP)}

On the efficacy and potential for use of innovative materials such as FRP or UHTSS, high strength stainless steels, applied in the form of a grid (Reticulatus System)
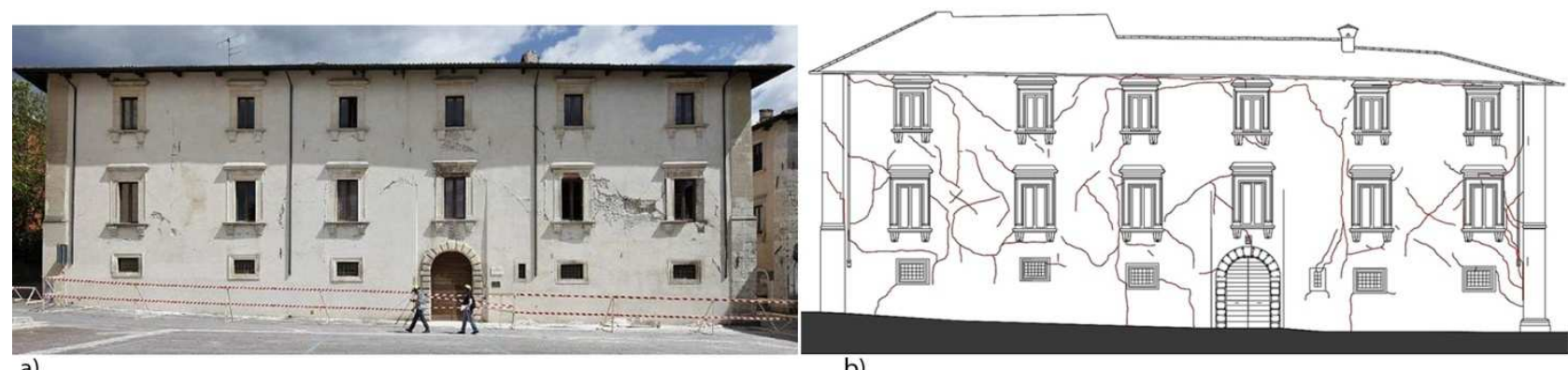

b)

Figure 5. Front elevation of Palazzo Branconio: a) picture taken from the author; b) cracking pattern 
in the field of seismic retrofit of masonry walls belonging to historical buildings, it has been widely written in the specific scientific literature [20-27].

The traditional timber frame reinforcements can be effectively replaced by a homologous frame, according to a similar geometric pattern, composed of natural basalt fiber strips, arranged in adherence to the wall front and glued to the wall itself by means of a GeoCalce (a KeraKoll patent), a hydraulic lime matrix compatible with the traditional binder present in the walls (Fig. 6). A more effective connection to the wall is obtained through the application of transversal elements, with function of diatones, equipped with gripping bow. The retrofit scheme described above (Fig. 7), eventually accompanied by a continuous basalt fiber net, placed on the opposite side of the wall, can guarantee a structural performance of exceptional efficiency in seismic conditions, without weighing down the original structure or substantially modifying the overall stiffness.

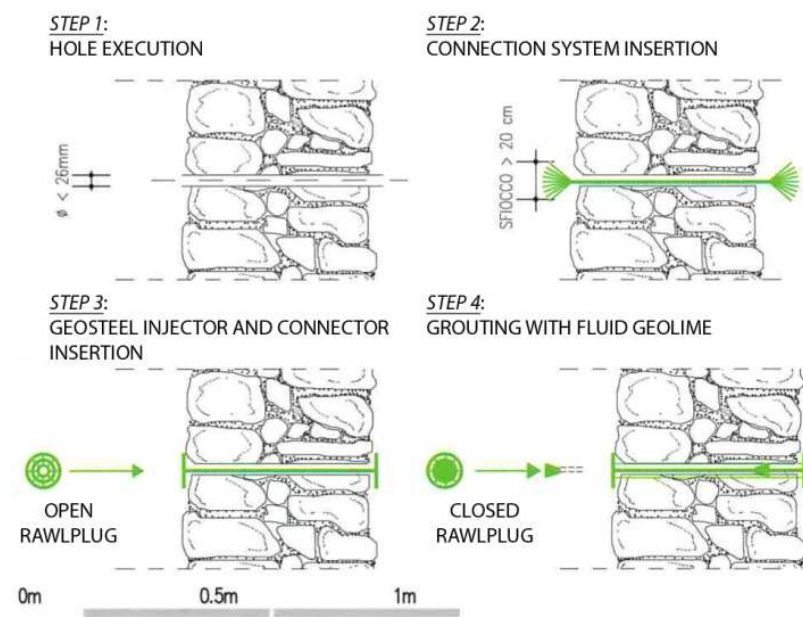

Figure 6. Application technique of natural basalt fiber strips (KeraKoll)

\section{Conclusions}

On the basis of examples from the past, such as the "Gaiola Pombalina" or the Bourbon concept system, reproposing its geometric patterns and, partly, the aims of the structural performance of the elements integrated into the wall, the paper deals with the design approach for post-seismic interventions aimed to the safeguarding of historical buildings in seismic areas. The traditional timber frame reinforcements are, in this case, substituted by the natural basalt fiber strips, arranged according to similar geometric patterns, connected to the masonry walls trough transversal elements, with function of diatones, equipped by gripping bow. The system seems to be able to guarantee an excellent resistance both to the shearing actions and to the combined compressive and bending ones.

\section{Acknowledgments}

The author wishes to thank DiaCon Srl, an academic Spin-Off of the University of Florence, which has experimented, from the point of view of executive design, the technology described in this paper.

\section{References}

1. P. Vitruvio, Dieci Libri di Architettura, Libro II Cap. X, T. Carunchio (Ed.), Bardi, Roma (2006)

2. N. Ruggieri, S. Galassi, G. Tempesta, Pompeii's Stabian Baths. Mechanical behaviour assessment of selected masonry structures during the 1st century seismic events, Int. J. Archit. Herit. 12, 5, 859-878 (2018) 10.1080/15583058.2017.1422571

3. N. Ruggieri, Timber "Science" in Herculaneum (Italy) during the 1st century A.D., Materials Science Forum (ISSN: 0255-5476), Trans Tech Publications, Proc. of 4th International Conference on Mechanical Structures and Smart Materials (4th ICMSSM2018) (22-23 September 2018, Shenzhen, China)

4. A. Amoroso, M. Bianchini, F. Di Gennaro, F. Fraioli, M. Merlo, Strutture semipogee nell'ager Fidenatis, in: Suburbium, 2. Il suburbio di Roma dalla fine dell'età monarchica alla nascita del sistema delle ville (V-II secolo a.c.), Roma 2009, pp. 347367

5. R. Langenbach, Learning from the past to protect the future: Armature crosswalls, Eng. Struct. 30, 8 20962100 (2008) 10.1016/j.engstruct.2008.04.028

6. R. Langenbach, Crosswalls instead of shearwalls: a proposed research project for the retrofit of vulnerable concrete buildings in earthquake areas based on traditional himis construction, Proc. of the Turkish $5^{\text {th }}$ National Conference on Earthquake Engineering (26-30 May 2003, Istambul, Turkey)

7. E. Poletti, G. Vasconcelos, Seismic performance of traditional half-timbered walls: experimental results, pp. 53-66, in: Ruggieri N., Tampone G., Zinno R. (Eds), Historical Hearthquake-Resistant Timber Frames in the Mediterranean Area, Springer, Cham, 2015, pp. 95-103 (2013) 10.1007/978-3-319-16187-7

8. S. Galassi, N. Ruggieri, G. Tempesta, Seismic

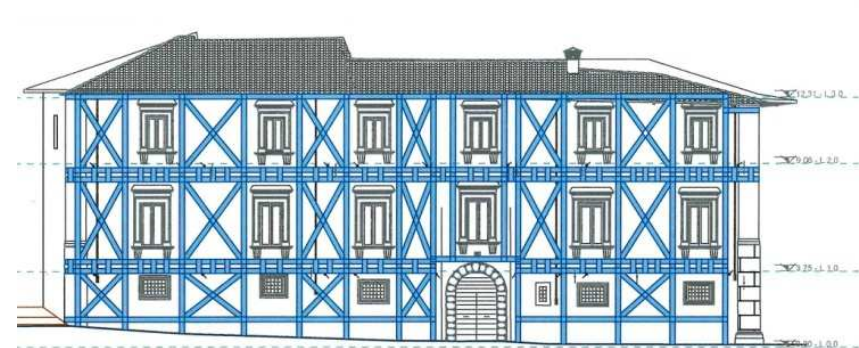

a)

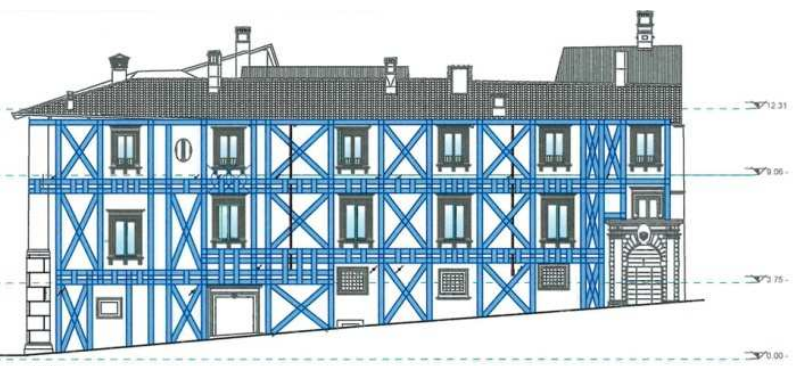

b)

Figure 7. BFRP strengthening intervention of Palazzo Branconio: a) front elevation; b) side elevation 
performance evaluation of timber-framed masonry walls. Experimental tests and numerical modelling, in: Ruggieri N., Tampone G., Zinno R. (Eds), Historical Hearthquake-Resistant Timber Frames in the Mediterranean Area, Springer, Cham, 2015, pp. 95-103, Proc. of 1st International Symposium on Historic Earthquake-Resistant Timber Frames in the Mediterranean Area, Cosenza, Italy (4-5 November 2013) 10.1007/978-3-319-16187-7_8

9. S. Galassi, N. Ruggieri, G. Tempesta, A novel numerical tool for seismic vulnerability analysis of ruins in archaeological sites, Int. J. Archit. Herit. (2018), 10.1080/15583058.2018.1492647

10. S. Galassi, N. Ruggieri, G. Tempesta, Ruins and archaeological artifacts: vulnerabilities analysis for their conservation through the original computer program BrickWORK, in: Aguilar, R., Torrealva, D., Moreira, S., Pando, M., Ramos, L.F. (Eds.), Structural Analysis of Historical Constructions, RILEM bookseries 18, Springer International Publishing, pp. 1839-1848 (2018) 10.1007/978-3319-99441-3_197, Proc. of 11th International Conference on structural analysis of historical constructions (SAHC2018)(11-13 September 2018, Cusco, Perù).

11. S. Galassi, M. Paradiso, BrickWORK SoftwareAided Analysis of Masonry Structures, IERI Procedia 7, 62-70 (2014), Special Issue 2013 International Conference on Applied Computing, Computer Science, and Computer Engineering (ICACC 2013), USA, December 2013, Elsevier B.V., ISSN: 2212-6678, 10.1016/j.ieri.2014.08.011

12. S. Galassi, G. Misseri, L. Rovero, G. Tempesta, Equilibrium analysis of masonry domes. On the analytical interpretation of the Eddy-Lévy graphical method, Int. J. Archit. Herit. 11, 8, 1195-1211 (2017) 10.1080/15583058.2017.1372823

13. S. Galassi, G. Tempesta, Analysis of Masonry Block Structures with Unilateral Frictional Joints, in: Proc. Int. Conf. on Electronic, Control, Automation and Mechanical Engineering (ECAME 2017), 19-20 November 2017, Sanya, China, DEStech Transactions on Engineering and Technology Research, 246-51, 10.12783/dtetr/ecame2017/18396

14. F. Pugi, S. Galassi, 2013 Seismic analysis of masonry voussoir arches according to the Italian building code, Ing. Sismica-Ital. 30 ,3, 33-55 (2013)

15. S. Galassi, G. Misseri, L. Rovero, G. Tempesta, Failure modes prediction of masonry voussoir arches on moving supports, Eng. Struct. 173, 706-717 (2018) 10.1016/j.engstruct.2018.07.015

16. M. Paradiso, S. Galassi, S. Benedetti, Stabilità di archi e volte in muratura: metodi tradizionali e calcolo automatico, in: Luis Villegas, Ignacio lombillo, Clara Liano, Haydee Blanco (Eds.), Patologia della Costruccion, Tecnologia de la Rehabilitacion y Gestion del Patrimonio, Proc. Conf Latinoamericano Patologie del costruito, tecniche di riabilitazione e gestione del patrimonio (Rehabend 2014), Santander, Spain, Gráficas Iguña, S.A. (2014)

17. M. Paradiso, S. Galassi, S. Benedetti, Il caratteristico Forte di San Fernando de Bocachica, Colombia, in:
Luis Villegas, Ignacio lombillo, Clara Liano, Haydee Blanco (Eds.), Patologia della Costruccion, Tecnologia de la Rehabilitacion y Gestion del Patrimonio, Proc. Conf. Latinoamericano Patologie del costruito, tecniche di riabilitazione e gestione del patrimonio (Rehabend 2014), Santander, Spain, Gráficas Iguña, S.A. (2014)

18. S. Galassi, L. Dipasquale, N. Ruggieri, G. Tempesta, Andalusian timber roof structure in Chefchaouen, Northern Morocco: construction technique and structural behavior, J. Archit. Eng. 24, 3, 04018012 (2018) 10.1061/(ASCE)AE.1943-5568.0000315

19. S. Galassi, N. Ruggieri, L. Dipasquale, G. Tempesta, Assessment of the Moroccan Vernacular Timber Roof: a Proposal for an Eco-Friendly Strengthening System, J. Architectural Conservation (in press).

20. M. Paradiso, S. Galassi, A. Borri, D. Sinicropi, "Reticolatus": an innovative reinforcement for irregular masonry. A numeric model, in: Paulo J. S. Cruz (Ed.), Structures and Architecture: Concepts, Applications and Challenges, CRC Press / Balkema, Taylor and Francis Group, London, Proc. 2nd Int. Conf. on Structure \& Architecture ICSA2013, Guimaraes, Portugal (2013)

21. M. Corradi, A. Borri, G. Castori, R. Sisti, The Reticulatus method for shear strengthening of fairfaced masonry, Bulletin of Earthquake Engineering 14, 12, 3547-3571 (2016) 10.1007/s10518-0160006-5

22. D. Sinicropi, E. Perria, S. Galassi, M. Paradiso, A. Borri, Artificial Ageing of Mortar Prisms Reinforced through Steel, Glass and Organic Fibers, Journal of Key Eng. Mat., A. Di Tommaso, C. Gentilini and G. Castellazzi (Eds.) 624, 4, 542-50 (2014) 10.4028/www.scientific.net/KEM.624.542

23. S. Galassi, A numerical procedure for failure mode detection of masonry arches reinforced with fiber reinforced polymeric materials, IOP Conf. Ser.: Mater. Sci. Eng. 369, 012038 (2018) 10.1088/1757899X/369/1/012038, Proc. of 5th Global Conference on Polymer and Composite Materials (PCM 2018) (10-13 April 2018, Kitakyushu City, Japan)

24. S. Galassi, Analysis of masonry arches reinforced with FRP sheets: experimental results and numerical evaluations, MATEC Web of Conferences 207: 01002, 10.1051/matecconf/201820701002, Proc. of International Conference on Metal Material Processes and Manufacturing (ICMMPM2018) (1920 July 2018, Jeju Island, South Korea)

25. A. Borri, G. Castori, M. Corradi, Intrados strengthening of brick masonry arches with composite materials, Compos. Part B-Eng. 42, 5, 1164-1172

(2011) 10.1016/j.compositesb.2011.03.005

26. G. Castori, A. Borri, M. Corradi, Behavior of thin masonry arches repaired using composite materials, Compos. Part B-Eng. 87, 311-321 (2016) 10.1016/j.compositesb.2015.09.008

27. A. Borri, G. Castori, M. Corradi, Strengthening of thin masonry arches, Key Eng. Mat. 624, 51-58 (2015) 10.4028/www.scientific.net/KEM.624.51 